\title{
Sven Petry
}

\section{Die Entgrenzung JHWHs}

Monolatrie, Bilderverbot und Monotheismus im Deuteronomium, in Deuterojesaja und im Ezechielbuch

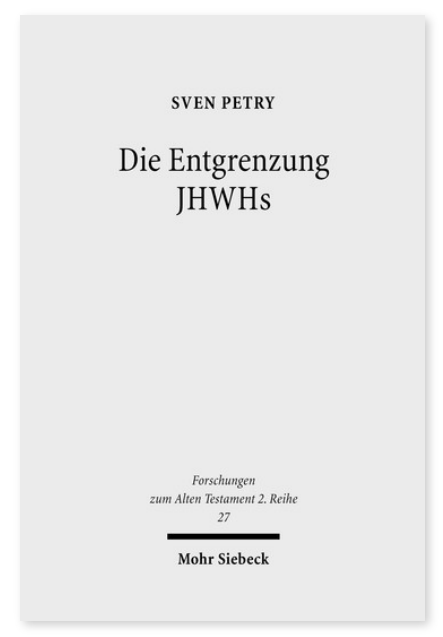

2007. XIII, 463 Seiten. FAT II 27

ISBN 978-3-16-151125-7

DOI 10.1628/978-3-16-151125-7

eBook PDF 109,00€

ISBN 978-3-16-149451-2

fadengeheftete Broschur 109,00€
Sven Petry schaltet sich in die Monotheismusdebatte ein, die in der alttestamentlichen Forschung seit knapp drei Jahrzehnten wieder lebhaft geführt wird. Aufbauend auf dem im Rahmen dieser Debatte erreichten Erkenntnisstand weist er die Entwicklung der JHWH-Verehrung von der faktischen oder praktischen Monolatrie der vorexilischen Königszeit zur programmatischen Monolatrie und zum exklusiven Monotheismus in exilisch-nachexilischer Zeit an den einschlägigen Texten selbst nach und stellt sie im Zusammenhang dar. Im Deuteronomium zeichnet er eine zwar nicht auf allen Stufen seiner Entstehung gleichermaßen breite, aber dennoch kontinuierliche Entwicklungslinie nach, ausgehend vom Kultzentralisationsgebot Dtn 12,13ff., dem »Höre Israel« Dtn 6,4 und der Bundesformel Dtn 26,17f. über das Erste Gebot des Dekalogs Dtn 5,7.9, nachträglich erweitert um das Bilderverbot Dtn 5,8, zum expliziten Monotheismus in Dtn 4. Er korreliert diese Entwicklungslinie mit dem monotheistischen Bekenntnis Deuterojesajas und zeigt, dass dieses das monolatrische Programm des Deuteronomiums voraussetzt, seinerseits jedoch dessen monotheistische Passagen beeinflusst hat. Sven Petry analysiert die einschlägigen Passagen des Ezechielbuches und weist auf, dass sie - anders als nach der traditionellen, auf dem Eigenzeugnis des Buches fußenden Datierung zu erwarten wäre - noch einen Schritt weiter gehen und die Konsequenzen des monotheistischen Bekenntnisses im Blick auf das Gottesbild und die innere Verfassung Israels bedenken.

Sven Petry Geboren 1976; Studium der ev. Theologie in Bethel, Bonn und Göttingen; 2007 Promotion; seit Herbst 2007 Vikar in der Evangelisch-Lutherischen Landeskirche Sachsens.
Jetzt bestellen:

https://mohrsiebeck.com/buch/die-entgrenzung-jhwhs-9783161511257?no_cache=1

order@mohrsiebeck.com

Telefon: +49 (0)7071-923-17

Telefax: +49(0)7071-51104 